\section{SANKSI ADMINISTRASI ATAS PELANGGARAN UNDANG - UNDANG NOMOR 4 TAHUN 2009 TENTANG PERTAMBANGAN MINERAL DAN BATUBARA $^{1}$ \\ Oleh: Tesalonika Roring ${ }^{2}$}

\begin{abstract}
ABSTRAK
Penelitian ini dilakukannya dengan tujuan adalah untuk mengetahui bagaimana terjadinya pelanggaran administrasi di bidang pertambangan mineral dan batubara dan bagaimana pemberlakuan sanksi administratif atas pelanggaran Undang-Undang Nomor 4 Tahun 2009 Tentang Pertambangan Mineral dan Batubara. Dengan menggunakan metode penelitian yuridis normatif, disimpulkan: 1 . Pelanggaran administrasi di bidang pertambangan mineral dan batubara terjadi apabila pemegang IUP (Izin Usaha Pertambangan) Izin Pertambangan Rakyat, (IPR) dan IUPK (Izin Usaha Pertambangan Khusus) yang melakukan pelanggaran hukum atas ketentuan-ketentuan di bidang pertambangan mineral dan batubara sebagaimana dimaksud pada Pasal 151 ayat (1) Undang-Undang Nomor 4 Tahun 2009 tentang Pertambangan Mineral dan Batubara. 2. Pemberlakuan sanksi administratif atas pelanggaran Undang-Undang Nomor 4 Tahun 2009 Tentang Pertambangan Mineral Dan Batubara berhak dilakukan oleh Menteri, gubernur, atau bupati/walikota sesuai dengan kewenangannya kepada pemegang IUP, IPR atau IUPK atas pelanggaran ketentuanketentuan hukum di bidang pertambangan mineral dan batubara. Sanksi administratif sebagaimana dimaksud pada ayat (1) berupa: peringatan tertulis; penghentian sementara sebagian atau seluruh kegiatan eksplorasi atau operasi produksi; dan/atau pencabutan IUP, IPR, atau IUPK.

Kata kunci: Sanksi Administrasi, Pelanggaran, Pertambangan Mineral Dan Batubara
\end{abstract}

\section{PENDAHULUAN}

\section{A. Latar Belakang}

Undang-Undang Dasar 1945 Pasal 33 ayat (3) menegaskan bahwa bumi, air, dan kekayaan alam yang terkandung di dalamnya dikuasai

\footnotetext{
${ }^{1}$ Artikel Skripsi. Dosen Pembimbing: Tonny Rompis, SH., $\mathrm{MH}$; Dr. Rodrigo F. Elias, SH., MH

2 Mahasiswa pada Fakultas Hukum Unsrat, NIM. 16071101071
}

oleh negara dan dipergunakan untuk sebesarbesar kemakmuran rakyat. Mengingat mineral dan batubara sebagai kekayaan alam yang terkandung di dalam bumi merupakan sumber daya alam yang tak terbarukan, pengelolaannya perlu dilakukan seoptimal mungkin, efisien, transparan, berkelanjutan dan berwawasan lingkungan, serta berkeadilan agar memperoleh manfaat sebesar-besar bagi kemakmuran rakyat secara berkelanjutan. ${ }^{3}$

Undang-Undang Nomor 4 Tahun 2009 Tentang Pertambangan Mineral Dan Batubara. Pasal 2. Pertambangan mineral dan/atau batubara dikelola berasaskan:

a. manfaat, keadilan, dan keseimbangan;

b. keberpihakan kepada kepentingan bangsa;

c. partisipatif, transparansi, dan akuntabilitas;

d. berkelanjutan dan berwawasan lingkungan.

Pasal 3. Dalam rangka mendukung pembangunan nasional yang berkesinambungan, tujuan pengelolaan mineral dan batubara adalah:

a. menjamin efektivitas pelaksanaan dan pengendalian kegiatan usaha pertambangan secara berdaya guna, berhasil guna, dan berdaya saing;

b. menjamin manfaat pertambangan mineral dan batubara secara berkelanjutan dan berwawasan lingkungan hidup;

c. menjamin tersedianya mineral dan batubara sebagai bahan baku dan/atau sebagai sumber energi untuk kebutuhan dalam negeri;

d. mendukung dan menumbuhkembangkan kemampuan nasional agar lebih mampu bersaing di tingkat nasional, regional, dan internasional;

e. meningkatkan pendapatan masyarakat lokal, daerah, dan negara, serta menciptakan lapangan kerja untuk sebesarbesar kesejahteraan rakyat; dan

f. menjamin kepastian hukum dalam penyelenggaraan kegiatan usaha pertambangan mineral dan batubara.

Apabila terjadinya pelanggaran administrasi di bidang pertambangan mineral dan batubara, maka pemberlakuan sanksi administratif atas pelanggaran Undang-Undang Nomor 4 Tahun 2009 Tentang Pertambangan Mineral Dan Batubara dapat dikenakan terhadap pihak-

\footnotetext{
${ }^{3}$ Penjelasan Atas Undang-Undang Nomor 4 Tahun 2009 Tentang Pertambangan Mineral Dan Batubara.
} 
pihak tertentu sebagai pemegang IUP (Izin Usaha Pertambangan) Izin Pertambangan Rakyat, (IPR) dan IUPK (Izin Usaha Pertambangan Khusus) akibat melakukan pelanggaran hukum atas ketentuan-ketentuan di bidang pertambangan mineral dan batubara sesuai dengan pengaturan Undang-Undang Nomor 4 Tahun 2009 tentang Pertambangan Mineral dan Batubara.

Penegakan hukum dijalankan untuk menjaga, mengawal dan menghantar hukum agar tetap tegak searah dengan tujuan hukum dan tidak dilanggar oleh siapapun. Kegiatan penegakan hukum merupakan tindakan penerapan hukum terhadap setiap orang yang perbuatannya menyimpang dan bertentangan dengan norma hukum, artinya hukum diberlakukan bagi siapa saja dan pemberlakuannya sesuai dengan mekanisme dan cara dalam sistem penegakan hukum yang telah ada. ${ }^{4}$ Dengan kata lain penegakan hukum sebagai suatu kegiatan untuk menjaga dan mengawal hukum agar tetap tegak sebagai suatu norma yang mengatur kehidupan manusia demi terwujudnya ketertiban, kemanan dan ketentraman masyarakat dalam menjalankan kehidupannya. ${ }^{5}$

\section{B. Rumusan Masalah}

1. Bagaimanakah terjadinya pelanggaran administrasi di bidang pertambangan mineral dan batubara?

2. Bagaimanakah pemberlakuan sanksi administratif atas pelanggaran UndangUndang Nomor 4 Tahun 2009 Tentang Pertambangan Mineral Dan Batubara?

\section{Metode Penelitian}

Penulisan ini disusun menggunakan metode penelitian hukum normatif. Bahan-bahan hukum yang diperlukan diperoleh dari hasil studi kepustakaan, seperti peraturan perundang-undangan sebagai bahan hukum primer. Literatur-literatur dan karya-karya ilmiah hukum sebagai hukum sekunder dan bahan-bahan hukum tersier dan juga seperti kamus-kamus hukum.

\footnotetext{
${ }^{4}$ Sadjijono.Polri Dalam Perkembangan Hukum Di Indonesia, (Editor) M. Khoidin, LaksBang PRESSindo, Yogyakarta. 2008. hlm. 61.

${ }^{5}$ lbid. hlm. 62.
}

\section{PEMBAHASAN}

\section{A. Pelanggaran Administrasi Di Bidang Pertambangan Mineral Dan Batubara}

Istilah kewenangan sering disebut dengan authority, gezag atau yuridiksi. Kewenangan adalah kekuasaan yang diformalkan baik terhadap segolongan orang tertentu, maupun kekuasaan terhadap sesuatu bidangpemerintahan tertentu secara bulat yang berasal dari kekuasaan legislatif maupun dari kekuasaan pemerintah. Pengertian ini berbeda dengan dengan wewenang yang dikenal juga dengan istilah competence atau bevoegdheid. Wewenang hanya mengenai sesuatu onderdil tertentu atau bidang tertentusaja. Jadi kewenangan merupakan kumpulan dari wewenang-wewenang (rechtsbevoegdhehen). Wewenang ini merupakan kemampuan untuk melakukan suatu tindakan hukum publik, atau secara yuridis, wewenang adalah kemampuan bertindakyang diberikan oleh Undang-Undang yang berlaku untuk melakukan hubunganhubungan hukum. ${ }^{6}$

Kewenangan negara merupakan kekuasaan yang diberikan oleh hukum kepada negara untuk mengurus, mengatur dan mengawasi pengelolaan bahan galian sehingga di dalam pengusahaan dan pemanfaatannya dapat meningkatkan kesejahteraan masyarakat. Kewenangan negara ini dilakukan oleh pemerintah. Penguasaan bahan galian tidak hanya menjadi monopoli pemerintah sematamata, tetapi juga diberikan hak kepada orang dan/atau badan hukum untuk mengusahakan bahan galian sehingga hubungan hukum antara negara dengan orang atau badan hukum harus diatur sedemikian rupa agar mereka dapat mengusahakan bahan galian secara optimal, agar orang atau badan hukum dapat mengusahakan bahan galian secara optimal, pemerintah/pemerintah daerah (provinsi/kabupaten/kota) memberikan izin kuasa pertambangan, kontrak karya, perjanjian karya pengusahaan batu bara kepada orang atau badan hukum tersebut. ${ }^{7}$

Undang-Undang Nomor 4 Tahun 2009 tentang Pertambangan Mineral dan Batubara, mengatur mengenai terjadinya pelanggaran adminsitrasi di bidang pertambangan mineral

\footnotetext{
${ }^{6}$ SF. Marbun. Pokok-Pokok Hukum Administrasi Negara. Liberty. Yogyakarta. 1997. hlm. 154.

${ }^{7}$ H. Salim, HS., Op.Cit, hlm. 9.
} 
dan batubara, sebagaimana dinyatakan pada Pasal 151 ayat (1) Menteri, gubernur, atau bupati/walikota sesuai dengan kewenangannya berhak memberikan sanksi administratif kepada pemegang IUP, IPR atau IUPK atas pelanggaran ketentuan sebagaimana dimaksud dalam:

1. Pasal 40 ayat (3), Pemegang IUP yang bermaksud mengusahakan mineral lain sebagaimana dimaksud pada ayat (2), wajib mengajukan permohonan IUP baru kepada Menteri, gubernur, dan bupati/walikota sesuai dengan kewenangannya.

2. Pasal 40 ayat (5), Pemegang IUP yang tidak berminat untuk mengusahakan mineral lain yang ditemukan sebagaimana dimaksud pada ayat (4), wajib menjaga mineral lain tersebut agar tidak dimanfaatkan pihak lain.

3. Pasal 41. IUP tidak dapat digunakan selain yang dimaksud dalam pemberian IUP.

4. Pasal 43 ayat (1) Dalam hal kegiatan eksplorasi dan kegiatan studi kelayakan, pemegang IUP Eksplorasi yang mendapatkan mineral atau batubara yang tergali wajib melaporkan kepada pemberi IUP. Ayat (2) Pemegang IUP Eksplorasi yang ingin menjual mineral atau batubara sebagaimana dimaksud pada ayat (1) wajib mengajukan izin sementara untuk melakukan pengangkutan dan penjualan.

5. Pasal 70. Pemegang IPR wajib:

a. melakukan kegiatan penambangan paling lambat 3 (tiga) bulan setelah IPR diterbitkan;

b. mematuhi peraturan perundangundangan di bidang keselamatan dan kesehatan kerja pertambangan, pengelolaan lingkungan, dan memenuhi standar yang berlaku;

c. mengelola lingkungan hidup bersama pemerintah daerah; d. membayar iuran tetap dan iuran produksi; dan

d. menyampaikan laporan pelaksanaan kegiatan usaha pertambangan rakyat secara berkala kepada pemberi IPR.

6. Pasal 71 ayat (1) Selain kewajiban sebagaimana dimaksud dalam Pasal 70 , pemegang IPR dalam melakukan kegiatan pertambangan rakyat sebagaimana dimaksud dalam Pasal 66 wajib menaati ketentuan persyaratan teknis pertambangan

7. Pasal 74 ayat (4) Pemegang IUPK yang bermaksud mengusahakan mineral lain sebagaimana dimaksud pada ayat (2), wajib mengajukan permohonan IUPK baru kepada Menteri.

8. Pasal 74 ayat (6) Pemegang IUPK yang tidak berminat untuk mengusahakan mineral lain yang ditemukan sebagaimana dimaksud pada ayat (4), wajib menjaga mineral lain tersebut agar tidak dimanfaatkan pihak lain.

9. Pasal 81 ayat (1) Dalam hal kegiatan eksplorasi dan kegiatan studi kelayakan, pemegang IUPK Eksplorasi yang mendapatkan mineral logam atau batubara yang tergali wajib melaporkan kepada Menteri.

10. Pasal 93 ayat (3) Pengalihan kepemilikan dan/atau saham sebagaimana dimaksud pada ayat (2) hanya dapat dilakukan dengan syarat: a. harus memberitahu kepada Menteri, gubernur, atau bupati/walikota sesuai dengan kewenangannya; dan b. sepanjang tidak bertentangan dengan ketentuan peraturan perundang-undangan.

11. Pasal 95. Pemegang IUP dan IUPK wajib:
a. menerapkan kaidah teknik pertambangan yang baik;
b. mengelola keuangan sesuai dengan sistem akuntansi Indonesia;
c. meningkatkan nilai tambah sumber daya mineral dan/atau batubara;
d. melaksanakan pengembangan dan pemberdayaan masyarakat setempat; dan
e. mematuhi batas toleransi daya dukung lingkungan.

12. Pasal 96. Dalam penerapan kaidah teknik pertambangan yang baik, pemegang IUP dan IUPK wajib melaksanakan:

a. ketentuan keselamatan dan kesehatan kerja pertambangan;

b. keselamatan operasi pertambangan;

c. pengelolaan dan pemantauan lingkungan pertambangan, termasuk kegiatan reklamasi dan pascatambang;

d. upaya konservasi sumber daya mineral dan batubara; 
e. pengelolaan sisa tambang dari suatu kegiatan usaha pertambangan dalam bentuk padat, cair, atau gas sampai memenuhi standar baku mutu lingkungan sebelum dilepas ke media lingkungan.

13. Pasal 97. Pemegang IUP dan IUPK wajib menjamin penerapan standar dan baku mutu lingkungan sesuai dengan karakteristik suatu daerah.

14. Pasal 98. Pemegang IUP dan IUPK wajib menjaga kelestarian fungsi dan daya dukung sumber daya air yang bersangkutan sesuai dengan ketentuan peraturan perundang-undangan.

15. Pasal 99 ayat (1) Setiap pemegang IUP dan IUPK wajib menyerahkan rencana reklamasi dan rencana pascatambang pada saat mengajukan permohonan IUP Operasi Produksi atau IUPK Operasi Produksi. Ayat (2) Pelaksanaan reklamasi dan kegiatan pascatambang dilakukan sesuai dengan peruntukan lahan pascatambang. Ayat (3) Peruntukan lahan pascatambang sebagaimana dimaksud pada ayat (2) dicantumkan dalam perjanjian penggunaan tanah antara pemegang IUP atau IUPK dan pemegang hak atas tanah.

16. Pasal 100 ayat (1) Pemegang IUP dan IUPK wajib menyediakan dana jaminan reklamasi dan dana jaminan pascatambang. Ayat (2) Menteri, gubernur, atau bupati/walikota sesuai dengan kewenangannya dapat menetapkan pihak ketiga untuk melakukan reklamasi dan pascatambang dengan dana jaminan sebagaimana dimaksud pada ayat (1). Ayat (3) Ketentuan sebagaimana dimaksud pada ayat (2) diberlakukan apabila pemegang IUP atau IUPK tidak melaksanakan reklamasi dan pascatambang sesuai dengan rencana yang telah disetujui.

17. Pasal 102. Pemegang IUP dan IUPK wajib meningkatkan nilai tambah sumber daya mineral dan/atau batubara dalam pelaksanaan penambangan, pengolahan dan pemurnian, serta pemanfaatan mineral dan batubara.

18. Pasal 103 ayat (1) Pemegang IUP dan IUPK Operasi Produksi wajib melakukan pengolahan dan pemurnian hasil penambangan di dalam negeri. Ayat (2) Pemegang IUP dan IUPK sebagaimana dimaksud pada ayat (1) dapat mengolah dan memurnikan hasil penambangan dari pemegang IUP dan IUPK lainnya. Ayat (3) Ketentuan lebih lanjut mengenai peningkatan nilai tambah sebagaimana dimaksud dalam Pasal 102 serta pengolahan dan pemurnian sebagaimana dimaksud pada ayat (2) diatur dengan peraturan pemerintah.

19. Pasal 105 ayat (3) Mineral atau batubara yang tergali dan akan dijual sebagaimana dimaksud pada ayat (1) dikenai iuran produksi. Ayat (4) Badan usaha sebagaimana dimaksud pada ayat (1) dan ayat (2) wajib menyampaikan laporan hasil penjualan mineral dan/atau batubara yang tergali kepada Menteri, gubernur, atau bupati/walikota sesuai dengan kewenangannya.

20. Pasal 107. Dalam melakukan kegiatan operasi produksi, badan usaha pemegang IUP dan IUPK wajib mengikutsertakan pengusaha lokal yang ada di daerah tersebut sesuai dengan ketentuan peraturan perundang-undangan.

21. Pasal 108 ayat (1) Pemegang IUP dan IUPK wajib menyusun program pengembangan dan pemberdayaan masyarakat.

22. Pasal 110. Pemegang IUP dan IUPK wajib menyerahkan seluruh data yang diperoleh dari hasil eksplorasi dan operasi produksi kepada Menteri, gubernur, atau bupati/walikota sesuai dengan kewenangannya.

23. Pasal 111 ayat (1) Pemegang IUP dan IUPK wajib memberikan laporan tertulis secara berkala atas rencana kerja dan pelaksanaan kegiatan usaha pertambangan mineral dan batubara kepada Menteri, gubernur, atau bupati/walikota sesuai dengan kewenangannya.

24. Pasal 112 ayat (1) Setelah 5 (lima) tahun berproduksi, badan usaha pemegang IUP dan IUPK yang sahamnya dimiliki oleh asing wajib melakukan divestasi saham pada Pemerintah, pemerintah daerah, badan usaha milik negara, badan usaha milik daerah, atau badan usaha swasta nasional.

25. Pasal 114 ayat (2) Apabila dalam kurun waktu sebelum habis masa penghentian sementara berakhir pemegang IUP dan IUPK sudah siap melakukan kegiatan 
operasinya, kegiatan dimaksud wajib dilaporkan kepada Menteri, gubernur, atau bupati/walikota sesuai dengan kewenangannya.

26. Pasal 115 ayat (2) Apabila penghentian sementara kegiatan usaha pertambangan diberikan karena keadaan yang menghalangi kegiatan usaha pertambangan sebagaimana dimaksud dalam Pasal 113 ayat (1) huruf $b$, kewajiban pemegang IUP dan IUPK terhadap Pemerintah dan pemerintah daerah tetap berlaku.

27. Pasal 125 ayat (3) Pelaku usaha jasa pertambangan wajib mengutamakan kontraktor dan tenaga kerja lokal.

28. Pasal 126 ayat (1) Pemegang IUP atau IUPK dilarang melibatkan anak perusahaan dan/atau afiliasinya dalam bidang usaha jasa pertambangan di wilayah usaha pertambangan yang diusahakannya, kecuali dengan izin Menteri.

29. Pasal 128 ayat (1) Pemegang IUP atau IUPK wajib membayar pendapatan negara dan pendapatan daerah.

30. Pasal 129 ayat (1) Pemegang IUPK Operasi Produksi untuk pertambangan mineral logam dan batubara wajib membayar sebesar 4\% (empat persen) kepada Pemerintah dan 6\% (enam persen) kepada pemerintah daerah dari keuntungan bersih sejak berproduksi.

31. Pasal 130 ayat (2) Pemegang IUP atau IUPK dikenai iuran produksi sebagaimana dimaksud dalam Pasal 128 ayat (4) huruf c atas pemanfaatan tanah/batuan yang ikut tergali pada saat penambangan.

\section{B. Pemberlakuan Sanksi Administratif Atas Pelanggaran Undang-Undang Nomor 4 Tahun 2009 Tentang Pertambangan Mineral Dan Batubara}

Undang-Undang Nomor 4 Tahun 2009 tentang Pertambangan Mineral dan Batubara, mengatur mengenai pemberlakuan sanksi administratif sebagaimana dinyatakan pada Pasal 151 ayat (2) (Sanksi administratif sebagaimana dimaksud pada ayat (1) berupa:

a. peringatan tertulis;

b. penghentian sementara sebagian atau seluruh kegiatan eksplorasi atau operasi produksi; dan/atau

c. pencabutan IUP, IPR, atau IUPK.
Sanksi administrasi merupakan perbuatan pemerintah guna mengakhiri suatu keadaan yang dilarang oleh kaidah hukum administrasi atau melakukan apa yang seharusnya ditinggalkan oleh para warga masyarakat karena bertentangan dengan undang-undang atau aturan hukum lainnya. ${ }^{8}$

Penempatan sanksi dalam suatu aturan hukum, merupakan bagian penutup yang sangat penting dalam setiap peraturan perundang-undangan termasuk dalam aturan hukum administrasi. Pada umumnya tidak ada gunanya memasukkan aturan-aturan hukum tentang kewajiban-kewajiban atau laranganlarangan bagi para warga dalam aturan hukum bidang administrasi negara, manakala aturanaturan mengenai tingkah laku tidak dapat dipaksakan secara tegas oleh aparat pemerintah atau lembaga/instansi maupun pejabat yang berwenang untuk itu. ${ }^{9}$

Larang; melarang; memerintahkan supaya tidak melakukan sesuatu; tidak memperbolehkan berbuat sesuatu. ${ }^{10}$

Pasal 151 ayat (1) Menteri, gubernur, atau bupati/walikota sesuai dengan kewenangannya berhak memberikan sanksi administratif kepada pemegang IUP, IPR atau IUPK atas pelanggaran ketentuan sebagaimana dimaksud dalam Pasal 40 ayat (3), Pasal 40 ayat (5), Pasal 41, Pasal 43, Pasal 70, Pasal 71 ayat (1), Pasal 74 ayat (4), Pasal 74 ayat (6), Pasal 81 ayat (1), Pasal 93 ayat (3), Pasal 95, Pasal 96, Pasal 97, Pasal 98, Pasal 99, Pasal 100, Pasal 102, Pasal 103, Pasal 105 ayat (3), Pasal 105 ayat (4), Pasal 107, Pasal 108 ayat (1), Pasal 110, Pasal 111 ayat (1), Pasal 112 ayat (1), Pasal 114 ayat (2), Pasal 115 ayat (2), Pasal 125 ayat (3), Pasal 126 ayat (1), Pasal 128 ayat (1), Pasal 129 ayat (1), atau Pasal 130 ayat (2).

Perbedaan antara sanksi administrasi dan sanksi pidana dapat dilihat dari tujuan pengenaan sanksi itu sendiri. Sanksi administrasi ditujukan kepada perbuatan pelanggarannya sedangkan sanksi pidana ditujukan kepada si pelanggar dengan memberi hukuman berupa nestapa. Sanksi administrasi dimaksudkan agar perbuatan pelanggaran itu

\footnotetext{
${ }^{8}$ Philipus. M. Hadjon. Pengantar Hukum Administrasi Indonesia. Gadjah Mada University Press, Yogyakarta 1994. hlm. 246.

${ }_{9} \mathrm{Ibid}, \mathrm{hlm} .245$.

${ }^{10}$ Sudarsono, Op.Cit, hlm. 242.
} 
dihentikan. Sifat sanksi adalah "reparatoir" artinya memulihkan pada keadaan semula. Di samping itu perbedaan antara sanksi pidana dan sanksi administrasi ialah tindakan penegakan hukumnya. Sanksi administrasi diterapkan oleh Pejabat Tata Usaha Negara tanpa harus melalui prosedur peradilan sedangkan sanksi pidana hanya dapat dijatuhkan oleh hakim pidana melalui proses peradilan. ${ }^{11}$

Penerapan sanksi pidana merupakan upaya terakhir (ultimum remedium) ketika instrumen hukum perdata atau hukum administrasi sudah tidak dapat dilaksanakan dengan baik. ${ }^{12}$

Menurut Philipus. M. Hadjon, wewenang menerapkan sanksi administrasi sebagai suatu konsep hukum publik terdiri atas sekurangkurangnya tiga komponen, yaitu:

a. komponen pengaruh; bahwa penggunaan wewenang dimaksudkan untuk mengendalikan perilaku subyek hukum,

b. komponen dasar hukum; bahwa wewenang itu selalu harus dapat ditunjuk dasar hukumnya, dan

c. komponen konformitas hukum; mengandung makna adanya standar wewenang, yaitu standar umum (semua jenis wewenang) dan standar khusus (untuk jenis wewenang tertentu). ${ }^{13}$

Pelayanan publik diartikan dengan pemberian layanan (melayani) keperluan orang atau masyarakat yang mempunyai kepentingan pada organisasi itu sesuai dengan aturan pokok dan tata cara yang telah ditetapkan. ${ }^{14}$ Penarikan kembali keputusan sebagai sanksi ini berkaitan erat dengan sifat keputusan itu sendiri. Bila keputusan bersifat terikat, maka keputusan tersebut harus ditarik sendiri oleh organ atau instansi yang mengeluarkan keputusan. Penarikan ini hanya mungkin dilakukan apabila peraturan perundangundangan yang menjadi dasar dikeluarkannya keputusan telah mengaturnya sebelum

\footnotetext{
${ }^{11}$ Philipus. M. Hadjon, dkk. Pengantar Hukum Administrasi Indonesia (Introduction To The Indonesian Administrative Law) Gadjah Mada University Press. Yogyakarta. 2008. hlm. 247.

${ }^{12}$ Andi Hamzah. Asas-asas Hukum Pidana Indonesia. Rineka Cipta. Jakarta, 2008. hlm. 8.

${ }^{13}$ Philipus. M. Hadjon, Op.Cit. hlm. 1.

${ }^{14}$ Lijan Poltak Sinambela. Reformasi Pelayanan PublikTeori, Kebijakan, Dan Implementasi. Bumi Aksara. Jakarta. 2006. hlm. 5.
}

keputusan itu dikeluarkan. Sedangkan keputusan yang bersifat bebas, maka penarikannya kadang-kadang ditentukan dalam peraturan perundang-undangan, kadangkadang tidak. ${ }^{15}$

Hal-hal yang dapat menjadikan sebab suatu keputusan tata usaha negara yang berupa perizinan dicabut sebagai bentuk sanksi adalah :

1. Pihak yang berkepentingan (penerima izin) tidak mematuhi pembatasanpembatasan,syarat-syarat atau ketentuan peraturan perundang-undangan yang dikaitkan pada izin tersebut;

2. Pihak yang berkepentingan (penerima izin) pada waktu mengajukan permohonan untuk mendapatkan izin telah memberikan data yang tidak benar atau tidak lengkap. Hal ini bermakna bahwa apabila data yang diberikan saat mengajukan permohonan izin benar, lengkap, dan tidak dipalsukan maka pemberian izin mungkin tidak akan diberikan (permohonan izin ditolak). ${ }^{16}$

Undang-Undang Nomor 4 Tahun 2009 tentang Pertambangan Mineral dan Batubara. Pasal 152. Dalam hal pemerintah daerah tidak melaksanakan ketentuan sebagaimana dimaksud dalam Pasal 151 dan hasil evaluasi yang dilakukan oleh Menteri sebagaimana dimaksud dalam Pasal 6 ayat (1) huruf j, Menteri dapat menghentikan sementara dan/atau mencabut IUP atau IPR sesuai dengan ketentuan peraturan perundang-undangan.

Pasal 153. Dalam hal pemerintah daerah berkeberatan terhadap penghentian sementara dan/atau pencabutan IUP dan IPR oleh Menteri sebagaimana dimaksud dalam Pasal 152, pemerintah daerah dapat mengajukan keberatan sesuai dengan ketentuan peraturan perundang-undangan.

Pasal 154 Setiap sengketa yang muncul dalam pelaksanaan IUP, IPR, atau IUPK diselesaikan melalui pengadilan dan arbitrase dalam negeri sesuai dengan ketentuan peraturan perundangundangan.

Pasal 155. Segala akibat hukum yang timbul karena penghentian sementara dan/atau pencabutan IUP, IPR atau IUPK sebagaimana dimaksud dalam Pasal 151 ayat (2) huruf $b$ dan

\footnotetext{
15 Ibid. hlm. 312

${ }^{16}$ Ibid.
} 
huruf c diselesaikan sesuai dengan ketentuan peraturan perundang-undangan.

Pasal 156. Ketentuan lebih lanjut mengenai tata cara pelaksanaan sanksi administratif sebagaimana dimaksud dalam Pasal 151 dan Pasal 152 diatur dengan peraturan pemerintah.

Pasal 157 Pemerintah daerah yang tidak memenuhi ketentuan sebagaimana dimaksud dalam Pasal 5 ayat (4) dikenai sanksi administratif berupa penarikan sementara kewenangan atas hak pengelolaan usaha pertambangan mineral dan batubara.

Izin (Vergunning) adalah suatu persetujuan dari penguasa berdasarkan undang-undang atau peraturan pemerintah untuk dalam keadaan tertentu menyimpang dari ketentuanketentuan larangan peraturan perundangundangan. Izin dapat juga diartikan sebagai dispensasi atau pelepasan/pembebasan dari suatu larangan. ${ }^{17}$

Perizinan adalah salah satu bentuk pelaksanaan fungsi pengaturan dan bersifat pengendalian yang dimiliki oleh pemerintah terhadap kegiatan-kegiatan yang dilakukan oleh masyarakat. Dengan memberikan izin, penguasa memperkenankan orang yang memohonnya untuk melakukan tindakantindakan tertentu yang sebenarnya dilarang demi memperhatikan kepentingan umum yang mengharuskan adanya pengawasan. Hal pokok pada izin, bahwa sesuatu tindakan dilarang kecuali diperkenankan dengan tujuan agar dalam ketentuan-ketentuan yang bersangkutan dilakukan dengan cara-cara tertentu. ${ }^{18}$

Dalam Hukum Administrasi, izin merupakan instrumen yuridis yang digunakan oleh pemerintah untuk mempengaruhi para warga agar mau mengikuti cara yang dianjurkan guna mencapai suatu tujuan konkrit. Sebagai suatu instrumen hukum, izin berfungsi sebagai ujung tombak atau alat yang bertujuan untuk mengarahkan, mengendalikan, merekayasa, dan merancang masyarakat adil makmur. Melalui izin dapat diketahui bagaimana gambaran masyarakat adil makmur itu terwujud, yang berarti persyaratan-persyaratan yang terkandung dalam izin merupakan

\footnotetext{
${ }^{17}$ Adrian Sutedi. Hukum Perizinan Dalam Sektor Pelayanan Publik, Sinar Grafika. Jakarta. 2011, hlm. 167-168.

${ }^{18} \mathrm{Ibid}, \mathrm{hlm} .168$.
}

pengendali dalam memfungsikan izin itu sendiri. ${ }^{19}$

\section{PENUTUP}

\section{A. Kesimpulan}

1. Pelanggaran administrasi di bidang pertambangan mineral dan batubara terjadi apabila pemegang IUP (Izin Usaha Pertambangan) Izin Pertambangan Rakyat, (IPR) dan IUPK (Izin Usaha Pertambangan Khusus) yang melakukan pelanggaran hukum atas ketentuanketentuan di bidang pertambangan mineral dan batubara sebagaimana dimaksud pada Pasal 151 ayat (1) Undang-Undang Nomor 4 Tahun 2009 tentang Pertambangan Mineral dan Batubara.

2. Pemberlakuan sanksi administratif atas pelanggaran Undang-Undang Nomor 4 Tahun 2009 Tentang Pertambangan Mineral Dan Batubara berhak dilakukan oleh Menteri, gubernur, atau bupati/walikota sesuai dengan kewenangannya kepada pemegang IUP, IPR atau IUPK atas pelanggaran ketentuan-ketentuan hukum di bidang pertambangan mineral dan batubara. Sanksi administratif sebagaimana dimaksud pada ayat (1) berupa: peringatan tertulis; penghentian sementara sebagian atau seluruh kegiatan eksplorasi atau operasi produksi; dan/atau pencabutan IUP, IPR, atau IUPK.

\section{B. Saran}

1. Pelanggaran administrasi di bidang pertambangan mineral dan batubara dapat dicegah apabila pemerintah melalui menteri yang memiliki kewenangan di bidang pertambangan mineral dan batubara melakukan pembinaan dan pengawasan terhadap penyelenggaraan pengelolaan usaha pertambangan yang dilaksanakan oleh pemerintah provinsi dan pemerintah kabupaten/kota sesuai dengan kewenangannya. Menteri dapat melimpahkan kepada gubernur untuk

\footnotetext{
${ }^{19}$ Ridwan. HR. Hukum Administrasi Negara. UII Press. Yogyakarta. 2003. hlm. 160.
} 
melakukan pengawasan terhadap penyelenggaraan kewenangan pengelolaan di bidang usaha pertambangan yang dilaksanakan oleh pemerintah kabupaten/kota. Gubernur dan bupati/walikota wajib melaporkan pelaksanaan usaha pertambangan di wilayahnya kepada Menteri. Pemerintah dapat memberi teguran kepada pemerintah daerah apabila dalam pelaksanaan kewenangannya tidak sesuai dengan Undang-Undang Nomor 4 Tahun 2009 tentang Pertambangan Mineral dan Batubara dan ketentuan peraturan perundang-undangan lainnya.

2. Pemberlakuan sanksi administratif atas pelanggaran Undang-Undang Nomor 4 Tahun 2009 Tentang Pertambangan Mineral Dan Batubara perlu didukung oleh pemerintah daerah. Apabila pemerintah daerah tidak melaksanakan ketentuan-ketentuan mengenai pemberlakuan sanksi administratif, maka Menteri dapat menghentikan sementara dan/atau mencabut IUP atau IPR sesuai dengan ketentuan peraturan perundangundangan. Dalam hal pemerintah daerah berkeberatan terhadap penghentian sementara dan/atau pencabutan IUP dan IPR oleh Menteri maka pemerintah daerah dapat mengajukan keberatan sesuai dengan ketentuan peraturan perundang-undangan.

\section{DAFTAR PUSTAKA}

Djamali Abdoel. Pengantar Hukum Indonesia. Rajawali Pers. PT. Raja Grafindo Persada. Jakarta. 2009.

Hadari Nawawi,. Pengawasan Melekat di Lingkungan Aparatur Pemerintah. Gelora Aksara Pratama, Jakarta. 1992.

Hadjon M. Philipus.. Pengantar Hukum Administrasi Indonesia. Gadjah Mada University Press, Yogyakarta 1994.

Hadjon M. Philipus., dkk. Pengantar Hukum Administrasi Indonesia (Introduction To The Indonesian Administrative Law) Gadjah Mada University Press. Yogyakarta. 2008.

--, Pengantar Hukum Administrasi Indonesia, Gadjah Mada Press University Yogyakarta. 2002.
Hamzah Andi. Terminologi Hukum Pidana, (Editor) Tarmizi, Ed. 1. Cet. 1. Sinar Grafika, Jakarta, 2008.

----------, Asas-asas Hukum Pidana Indonesia. Rineka Cipta. Jakarta, 2008.

Hariri Muhwan Wawan. Pengantar Ilmu Hukum, Cet. 1. CV. Pustaka Setia Bandung. 2012.

Helmi. Hukum Perizinan Lingkungan Hidup, Cetakan Pertama. Sinar Grafika. Jakarta. 2012.

Ridwan Juniarso. H. dan Achmad Sodik Sudrajat, Hukum Adminsitrasi Negara dan Kebijakan Pelayanan Publik, Cetakan I. Nuansa. Bandung. 2010.

HR. Ridwan, Hukum Adminstrasi Negara, Edisi I. Cet. 4. PT. RadjaGrafindo, Jakarta, 2006. --, Hukum Administrasi Negara. UII Press. Yogyakarta. 2003.

HS. Salim H., Hukum Pertambangan di Indonesia, Cetakan k-5. PT. RajaGrafindo Persada, Jakarta, 2010.

Husni Lalu, Pengantar Hukum Ketenagakerjaan Indonesia, Edisi Revisi, PT. RajaGrafindo, Jakarta, 2008.

Machmud Syahrul. Penegakan Hukum Lingkungan Indonesia. (Penegakan Hukum Administrasi. Hukum Perdata. Dan Hukum Pidana Menurut UndangUndang No. 32 Tahun 2009) Graha IImu. Yogyakarta.Graha IImu, Bandung. 2012.

Mahmud Marzuki Peter, Penelitian Hukum, Edisi Pertama Cetakan ke-2, Kencana Prenada Media Group, Jakarta, 2006.

Marbun Rocky, Deni Bram, Yuliasara Isnaeni dan Nusya A., Kamus Hukum Lengkap (Mencakup Istilah Hukum \& Perundang-Undangan Terbaru, Cetakan Pertama, Visimedia, Jakarta. 2012.

Marbun SF.. Pokok-Pokok Hukum Administrasi Negara. Liberty. Yogyakarta. 1997.
Muladi dan Dwidja Priyatno, Pertanggungjawaban Pidana Korporasi. Kencana Prenada Media Group. Jakarta. 2010.

Mulyadi Mahmud dan Feri Antoni Surbakti, Politik Hukum Pidana Terhadap 
Kejahatan Korporasi, Cetakan Pertama, PT. Sofmedia, Jakarta, 2010.

Nuh Muhammad, Etika Profesi Hukum, CV Pustaka Setia, Bandung, 2011.

Prins W.F dan R. Kosim Adisapoetra, Pengantar Hukum Ilmu Administrasi Negara. Pradnya Paramita, Jakarta. 1983.

Purbopranoto Kuntjoro, Perkembangan Hukum Administrasi Indonesia, Binacipta, Jakarta, 1981.

Putra Bagus Wyasa Ida, Hukum Bisnis Pariwisata, Cetakan Pertama. PT. Refika Aditama, Bandung, 2003.

Rahardjo Satjipto, Ilmu Hukum, Cetakan ke- IV, PT. Citra Aditya Bakti, Bandung, 2006. -, Hukum dan Perubahan Sosial Suatu Tinjauan Teoretis Serta PengalamanPengalaman di Indonesia. Cetakan Ketiga Genta Publishing. Yogyakarta. 2009.

Sadjijono. Polri Dalam Perkembangan Hukum Di Indonesia, (Editor) M. Khoidin, LaksBang PRESSindo, Yogyakarta. 2008.

Sarwoto. Dasar-dasar Organisasi dan Manajemen, Ghalia Indonesia. Jakarta. 1994.

Silondae Akbar Arus dan Wirawan B. Ilyas, Pokok-Pokok Hukum Bisnis, Salemba Empat, Jakarta, 2011.

Sinambela Poltak Lijan. Reformasi Pelayanan Publik-Teori, Kebijakan, Dan Implementasi. Bumi Aksara. Jakarta. 2006.

Soekanto Soerjono dan Sri Mamudji, Penelitian Hukum Normatif Suatu Tinjauan Singkat, PT Raja Grafindo Persada, Jakarta. 1995.

Spelt N.M. dan J.B.J.M. ten Berge, Pengantar Hukum Perizinan, (Penyunting) Philipus. M. Hadjon, Yuridika. Surabaya. 1993.

Sudarsono, Kamus Hukum, Cetakan Keenam, PT. Rineka Cipta, Jakarta, 2009.

Sudrajat Nandang, Teori dan Praktik Pertambangan Indonesia Menurut Hukum, Cet. 1. Pustaka Yustisia, Yogyakarta. 2010.

Supramono Gatot, Hukum Pertambangan Mineral dan Batu Bara di Indonesia, PT. Rineka Cipta, Jakarta, 2012.
Sutedi Adrian. Hukum Perizinan dalam Sektor Pelayanan Publik. Sinar Grafika. Jakarta. 2009.

------------, Hukum Perizinan Dalam Sektor Pelayanan Publik, Sinar Grafika. Jakarta. 2011.

Syahrin Alvi, Beberapa Isu Hukum Lingkungan Kepidananaan, Cetakan Revisi, PT. Sofmedia, Jakarta, Mei 2009.

Usman, Aspek-Aspek Hukum Perbankan di Indonesia. Penerbit Gramedia Pustaka Utama. Jakarta. 2001.

Yamin Muhammad, Tindak Pidana Khusus, CV. Pustaka Setia, Cetakan 1. Bandung, 2012. 